\title{
The Impact Interactive Learning Media on The Learning Outcomes of Fifth Grade Social Science Knowledge in Elementary Schools
}

\author{
Vina Iasha ${ }^{1}$, Reza Rachmadtullah ${ }^{2}$, Ajat Sudrajat ${ }^{3}$, Dewi Hartanti ${ }^{4}$ \\ \{vina.iasha@gmail.com ${ }^{1}$, rezarachmadtullahreza@gmail.com², ajatpgsd@yahoo.com ${ }^{3}$, \\ dewi.hartanti@yahoo.com $\left.{ }^{4}\right\}$ \\ Universitas Negeri Jakarta, Indonesia ${ }^{1234}$
}

\begin{abstract}
This study aims to determine influence the interactive learning media has on the learning outcomes of social science. The method used in this study uses the experimental method. Data collection techniques used in this study were tests and observations. The data analysis technique used is descriptive statistics and t-test. The sample of this study amounted to 100 elementary school students. The results of this study indicate that there is a significant effect of the use of interactive learning media on the results of learning social science because learning media makes it easy for teachers to deliver learning material, students find it easier to receive lessons using learning media rather than using conventional learning.
\end{abstract}

Keywords: interactive learning media, the learning outcomes, social science

\section{Introduction}

The development of science and technology has brought very significant changes to various dimensions of human life, both in the economy, social, culture and education. Therefore, for education not to be left behind from the development of Science and Technology, adjustments need to be made, especially those who are associated with teaching factors in schools. One of these factors is learning media that need to be learned and mastered by the teacher, so that they can convey the learning material to the students in an efficient and effective manner [1], [2].

Learning Social science knowledge is very important for the level of elementary school education because students who come to school come from different environments. Their introduction of the social life in which they are members is colored by their environment [3], [4]. The social science learning material especially in elementary schools must be well conveyed, especially with the characteristics of fifth grade elementary school students who are abstract teachers must utilize learning media that are easily accepted by students as a means of delivering messages[5].

Media education as one source of learning helps teachers enrich students' insights [3]. The various forms and types of educational media used by teachers become a source of knowledge for 
students [6]. Media as a learning resource is recognized as an auditive, visual, and audiovisual tool. The use of these three types of learning resources is not arbitrary, but must be adapted to the formulation of international objectives and of course with the competence of the teacher itself and so on. So teachers who are good at using media are teachers who can manipulate the media as a source of learning and channel information from material delivered to students in the learning process [7],

Interactive learning media is a combination of text, images, animation using the adobe flash player application, which is packaged in an interactive CD form so students can operate on a computer[8]. Further learning is done by using interactive learning media centered on students so that learning becomes active and interactive, students feel younger to understand learning material so that the use of learning learning using interactive learning media can improve student learning outcomes [9]. Developing multimedia applications can contribute to solving some problems in education, if the government really wants to use multimedia applications as an effective tool to improve learning[10].The use of interactive learning media has a positive impact on the learning process can increase motivation, self-confidence so that it can help increase students' interest and learning achievement[11]. The use of interactive learning media has a positive impact on cognitive achievement, academic achievement, understanding and application[12].

Interspersed with the opinions of Adi Prawiro Sasmito, and Andjrah Hamzah Irawan[13] in the research of interactive learning media as one of the learning media that supports the teaching and learning process in fifth grade elementary schools easily understood materially and easier for students to see things that real or object. provide more value to help educators in providing interesting, fun and easy-to-understand science education to improve the performance of elementary school students.

Based on the study of the literature above, this study aims to determine whether there is an influence of the use of interactive learning media on the results of learning social science in elementary schools. This research is expected to provide new knowledge for teachers so they can choose to teach using interactive learning media.

\section{Method}

This study aims to determine whether there is an influence of the use of interactive learning media on the learning outcomes of fifth grade social science knowledge in elementary schools. The method used in this study is using the research design method "One Groups Pretest-Posttest Design", which is the research design that has a pretest before being treated and posttest after being treated.

The sample in this study was determined using random sampling techniques. The random sampling technique is a random sampling method, where samples are taken based on classes rather than individuals. The sample in this study were 100 fifth grade elementary school students in East Jakarta DKI Jakarta

The instrument used in this study is a test of student learning outcomes in the form of objective questions (multiple choices) which have 4 answer choices (a, b, c, and d). The correct questions are given a score of 1 and the questions answered are incorrectly given a score of 0 , with 
the number of questions as many as 40 questions. Prior to the actual research, a pilot test was conducted to determine the reliability of the instrument and to achieve the desired objective of this study. The reliability of this set of instrument is .70 .30 .

The data analysis technique in this study is that after obtaining the pretest and posttest results data then proceed with analyzing the data and calculating the two-mean difference test (t-test). This analysis aims to determine the magnitude of the comparison between pretets and postets. The collected data were analyzed using SPSS software. The research data set can be accessed in osf.io Open Science Framework.

\section{Results}

The results of this study explain the differences between before using interactive learning media and after using interactive learning media as follows:

Table 1. Test for differences in the two averages (t-test) Pretest and Posttest

\begin{tabular}{|c|c|c|c|c|c|}
\hline \multicolumn{6}{|c|}{ Paired Samples Statistics } \\
\hline & & Mean & $\mathrm{N}$ & Std. Deviation & Std. Error Mean \\
\hline \multirow[t]{2}{*}{ Pair 1} & Pretest & 61.33 & 100 & 7.436 & .744 \\
\hline & Postetst & 81.12 & 100 & 6.652 & .665 \\
\hline \multicolumn{6}{|c|}{ Paired Samples Correlations } \\
\hline & & & $\mathrm{N}$ & Correlation & Sig. \\
\hline Pair 1 & Pretest & stetst & 100 & .346 & .000 \\
\hline
\end{tabular}

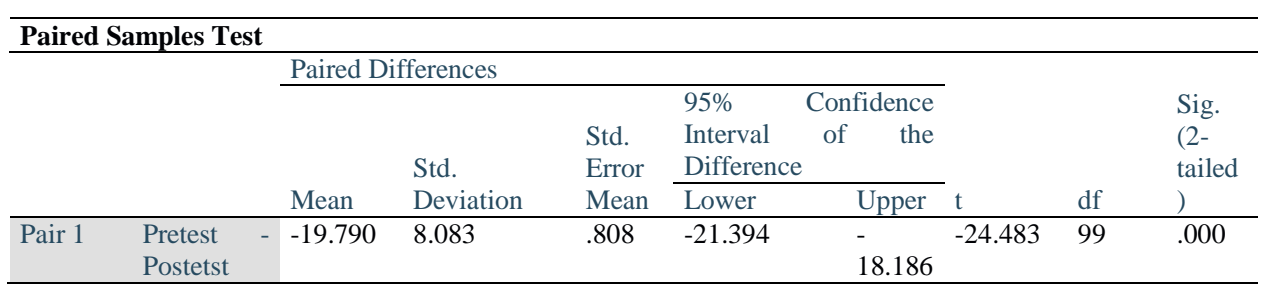

Based on calculations in the Paired Samples Statistics table, the average learning outcomes of Social Sciences before using the Media are interactive learning 61.33 and standard deviation of 7.436 and after using integrative learning media at 81.12 with standard deviation of 6.652 . This means that descriptively there are differences in the average learning outcomes of Social Sciences before and after using integrative learning media. 
In the Paired Sample Corelations table, the correlation coefficient scores obtained from the results of learning social science before and after being given learning using interactive learning media amounted to 0,346 with the sig number, or $\mathrm{p}$-value $=0,00050.05$ or not significant.

In the Paired Sample Test table, the difference in mean $=-19,790$ means that the score of Social Sciences learning outcomes is complete after and before using interactive learning media. The positive price is meaningful after being given interactive learning media, the score of Social Sciences learning outcomes is higher than before being given interactive learning media. Furthermore, in this table the standard error mean also shows that the standard error rate is the average difference. Furthermore, the most important result of this table is the price of statistics $\mathrm{t}=$ $-24,483$ with db 99 and significant numbers. Or p-value $0,000<0,05$ or $\mathrm{H} 0$ is rejected. Thus it can be concluded that there are significant differences in social science learning outcomes between before using interactive learning media obtained an average of 61.33 while after using interactive learning media amounting to 81.12.

\section{Discussion}

Based on the results of the research obtained, it is known that there is a significant effect between the use of interactive learning media on the learning outcomes of social science in fifth grade students in elementary school. This is because that the selection of learning media that is in accordance with the characteristics of students will help the success of the instructor in learning [2]. In detail the function of the media allows students to see objects that are present but it is difficult to see in plain view through the mediation of images, portraits, slides, and the like resulting in students getting a real picture [14]. The use of interactive learning media has benefits and functions as a means for teachers to be able to convey subject matter to be more interesting, not only monotonous, students are not only invited to fantasize and imagine but students can see reality even if only through pictures or videos [15].Interactive Learning Media is one of the media that can be used to deliver learning material to students very effectively and efficiently. The main advantage of interactive learning media is that interactivity itself opens up opportunities for interaction between users and the media[16].

\section{Conclusion}

The conclusion in this study is that learning using interactive media in class $\mathrm{V}$ social science subjects in elementary schools can condition students to learn more independently and actively. The use of interactive learning media can also address the problem of limited ability to absorb students and the limitations of teachers in the teaching and learning process in the classroom, and can bridge the problem of low actualization of students so that material that has not been understood can be explored through this interactive media-based learning. 


\section{References}

[1] A. Arsyad, Media Pembelajaran. Jakarta: Raja Grafindo Persada, 2014.

[2] R. Rachmadtullah, Nadiroh, Z. MS, and M. S. Sumantri, "Development of Interactive Learning Media on Civic Education Subjects in Elementary School Reza," in Advances in Social Science, Education and Humanities Research, 2018, vol. 251, pp. 293-296.

[3] S. D. Akbar and H. Sriwiyana, Pengembangan kurikulum dan pembelajaran ilmu pengetahuan sosial. Malang: Cipta Media, 2011.

[4] W. Gunawan, E. P. Kalensun, A. N. Fajar, and Sfenrianto, "E-Learning through social media in the virtual learning environment," IOP Conf. Ser. Mater. Sci. Eng., vol. 420, p. 012110, Oct. 2018.

[5] M. Anshari, Y. Alas, and L. S. Guan, "Developing online learning resources: Big data, social networks, and cloud computing to support pervasive knowledge," Educ. Inf. Technol., vol. 21, no. 6, pp. 1663-1677, Nov. 2016.

[6] M. S. Sumantri, Strategi Pembelajaran Teori dan Praktik Ditingkat Pendidikan Dasar. Jakarta: Rajawali Pres, 2015.

[7] Akrim, "Media Learning in Digital Era," in Advances in Social Science, Education and Humanities Research, 2018, vol. 231, no. Amca, pp. 458-460.

[8] S. Nan, "Multimedia Image Technology and Computer Aided Manufacturing Engineering Analysis," in IOP Conference Series: Materials Science and Engineering, 2018, vol. 317, p. 012046.

[9] F. Wang, W. Li, R. E. Mayer, and H. Liu, "Animated pedagogical agents as aids in multimedia learning: Effects on eye-fixations during learning and learning outcomes.," J. Educ. Psychol., vol. 110, no. 2, pp. 250-268, Feb. 2018.

[10] Munir, H. Sutarno, and N. S. Aisyah, "The development of interactive multimedia based on auditory, intellectually, repetition in repetition algorithm learning to increase learning outcome," $J$. Phys. Conf. Ser., vol. 1013, p. 012102, May 2018.

[11] D. Pujiastuti, A. Idrus, and Emosda, "Pengembangan Media Pembelajaran PKn Berbasis Multimedia Interaktif untuk SMP Kelas VIII," Tekno-Pedagogi, vol. 4, no. 1, pp. 1-6, 2014.

[12] Daryanto, Media Pembelajaran, Peranannya Sangat Penting dalam Mencapai Tujuan Pembelajaran. Yogjakarta: Gava Media., 2014.

[13] S. A. Prawiro and A. H. Irawan, "Perancangan Media Pembelajaran Interaktif Ilmu Pengetahuan Alam Untuk Siswa Kelas 4 SD Dengan Metode Learning The Actual Object," J. Sains dan Seni ITS, vol. 1, no. 1, pp. F28-F23, 2012.

[14] M. S. Sumantri and R. Rachmadtullah, "The effect of learning media and self regulation to elementary students' history learning outcome," Adv. Sci. Lett., vol. 22, no. 12, pp. 4104-4108, 2016.

[15] R. Rachmadtullah, Z. Ms, and M. S. Sumantri, "Development of computer - based interactive multimedia : study on learning in elementary education," Int. J. Eng. Technol., vol. 7, no. 4, pp. 2035-2038, 2018.

[16] V. Iasha, M. S. Sumantri, S. Sarkadi, and R. Rachmadtullah, "Development Media Interactive Learning in Education Pancasila and Citizenship Education to Improve Tolerance of Students in Elementary School," in Advances in Social Science, Education and Humanities Research, 2018, vol. 251, no. Acec, pp. 311-314. 